УДК 339.543

П. В. ЗАХАРЧЕНКО, О. П. ЮДІЧЕВА, О. К. ПАЛАМАРЧУК

Київський національний університет будівниитвв і архітектури

\title{
ДОСЛІДЖЕННЯ АЛГОРИТМУ КОДУВАННЯ ШПАЛЕР РІЗНИХ ТИПІВ ЗА УКТЗЕД 3 МЕТОЮ ЇХ ПРАВИЛЬНОГО МИТНОГО ОФОРМЛЕННЯ
}

\author{
П. В. ЗАХАРЧЕНКО, О. П. ЮДИЧЕВА, А. К. ПАЛАМАРЧУК \\ Киевский национальный университет строительства и архитектуры \\ ИССЛЕДОВАНИЕ АЛГОРИТМА КОДИРОВАНИЯ ОБОЕВ \\ РАЗЛИЧНЫХ ТИПОВ ПО УКТВЭД С ЦЕЛЬЮ ИХ ПРАВИЛЬНОГО \\ ТАМОЖЕННОГО ОФОРМЛЕНИЯ
}

\author{
P. ZAKHARCHENKO, O. YUDICHEVA, O. PALAMARCHUK \\ Kiev National University of Construction and Architecture
}

\section{ALGORITHM ANALYSISOF LIQUID WALLPAPER CODING ACCORDING TO UKTZED WITH THE PURPOSE OF PROPER CUSTOMS CLEARANCE}

\section{https://doi.org/10.36910/6775-2310-5283-2019-12-11}

\begin{abstract}
Мета. Дослідження алгоритму кодування шиалер за УКТЗЕД з метою їх митного оформлення.
\end{abstract}

Методика. Під час дослідження використано системний аналіз, методи узагальнення $i$ порівняння даних із проблеми дослідження на основі вивчення джерел літератури.

Результати. Рідкі шпалери - це суха сипуча суміш, що складається зі спеціально підібраних компонентів: волокон бавовни, целюлози, вовни, шовку, акрилу тощо $i$ зв'язуючого компоненту, тобто клею карбоксиметилцелюлози. Вони відрізняються від традииійних шпалер також технологією приготування $i$ нанесенням; їх класифікачія $i$ кодування теж має свої особливості. У мережевих магазинах «Епіцентр-К» представлені рідкі шпалери TM «Silk Plaster» (виробництво - Латвія), імпортером яких в Україну є ТОВ «Фасад». Правильність їх кодування забезпечить безперебійне виконання робіт під час декларування, чіткість проведення митного контролю. За ДКПП рідкі шпалери мають код 20.30.12-90.00 "Фарби та лаки, інші, на основі синтетичних полімерів, н. в. і. у.», тобто вони віднесені до секиії С «Продукиія переробної промисловості». Під час встановлення коду за УКТЗЕД спочатку було встановлено - рідкі шпалери є нехарчовою продукцією $i$ відносяться до хімічної продукиії, тобто можуть бути класифіковані у розділі IV «Продукція хімічної та пов'язаних з нею галузей промисловості». Цей розділ містить 11 груп. Аналіз приміток та пояснень до розділу IV дає можливість віднести рідкі шпалери до групи 32 «Екстракти дубильні або барвні; таніни та їх похідні, барвники, пігменти та інші фарбувальні матеріали, фарби і лаки, замазки та інші мастики; чорнило, туш». Відповідно до пояснень до групи 32, рідкі шпалери - це невогнетривкі суміші для підготовлення поверхонь. Отже, код рідких шпалер за УКТЗЕД -3214900090. 
Наукова новизна. Проведено вивчення рідких шпалер TM "Silk Plaster» як об'єкта класифікації для иілей митного оформлення, обгрунтування рівнів класифікації, надано класифікаційне рімення.

Практична значимість. Правильне визначення коду рідких шпалер TM «Silk Plaster» за УКТЗЕД є важливим для тарифного та нетарифного регулювання, під час обробки $i$ підготовки міжнародних документів, статистичних спостережень тощо.

Ключові слова: кодування, рідкі шпалери, класифікація, ТОВ «Фасад», митне оформлення, код, УКТЗЕД

Постановка проблеми у загальному вигляді та іï зв'язок із важливими науковими чи практичними завданнями. Враховуючи те, що Україна з кожним роком дедалі більше інтегрується у світове співтовариство, надзвичайно актуальною постає задача забезпечення наших громадян високоякісними товарами та послугами. Потрібно зауважити, що деякі товари в нашій країні не виробляються, тому їх приходиться закуповувати за кордоном. У країн з добре розвинутою економікою експорт переважає над імпортом або, як мінімум, вони збалансовані.

У 2018 р. Україна торгувала з 212 країнами світу. Найбільшим торговим партнером в останні роки залишається Євросоюз. 42-44 \% товарів та послуг Україна поставляє на експорт в Свропу; основний товар, який імпортує наша країна, - це енергоносії [1]. В той же час багато видів високотехнологічної продукції, яка виробляється (або могла би вироблятися) в Україні, завозиться в країну по імпорту.

Задля митних цілей усі товари, які обертаються у міжнародній торгівлі, систематизовані в УКТ ЗЕД. У 1950 р. в Брюсселі було підписано Конвенцію щодо створення товарної номенклатури. Країни, що підписали документ, були зобов'язані переглянути митні тарифи відповідно до затверджених принципів. Вони мали на меті уніфікацію товарної номенклатури таким чином, щоб визначивши загальні принципи іiі побудови, зберегти за собою, беручи до уваги інтереси національної економіки, право проводити кодування 3 урахуванням особливостей вітчизняного виробництва.

Кожен товар в УКТ ЗЕД має свій власний код, але для його правильного визначення необхідно дотримуватися деяких умов, зокрема, потрібні:

- точне найменування товару;

- точна характеристика товару;

- знання структури і побудови класифікатора.

Найменування товару сформульовано відповідно до назв, що прийняті у Гармонізованій системі опису та кодування товарів (ГС) та Комбінованою 
номенклатурою товарів Європейського Союзу. У 1983 р. було завершено створення Гармонізованої системи, яка була введена у національну систему зовнішньоекономічної діяльності України Указом Президента від 17.05.2002 №466/2002 «Про приєднання до Міжнародної конвенції про Гармонізовану систему опису та кодування товарів» [2]. Кодування товарів має технічний характер, дозволяючи подати об’єкт, що класифікується, у вигляді знака або групи знаків. Країни, що ввели норми ГС в національні законодавства, не беруть на себе жодних зобов'язань щодо ставок мита, але зобов'язуються не змінювати класифікацію та код товарів на рівні перших 6 знаків [3].

Загалом, товарна номенклатура, яка застосовується переважно при митно-тарифному регулюванні, має досить універсальний характер i використовується не лише для стягнення мита, а й у випадках [4]:

- ведення статистики зовнішньої торгівлі;

- $\quad$ визначення кола товарів, на які поширюються певні обмеження чи субсидії;

- визначення номенклатури підакцизних товарів чи товарів, до яких надаються пільги в оподаткуванні ПДВ;

- $\quad$ визначення правил походження чи публікації пропозицій державних закупівель.

Вчені Київського національного університету будівництва та архітектури (КНУБА) разом 3 фахівцями Академії будівництва України (АБУ) та спеціалістами провідних європейських будівельних компаній КНАУФ, Хенкель-Баутехнік, БАСФ протягом більш ніж 15 років впроваджують у будівельну практику та освітній процес сухі системи будівництва. Це системи, які для свого влаштування не потребують (або мінімально потребують) воду: гіпсокартонні, гіпсоволокнисті панелі, сухі будівельні суміші, волокниста або пінополістирольна теплоізоляція, стінові вироби з ніздрюватого автоклавного бетону тощо. Окреме місце серед них посідають системи внутрішнього оздоблення стін. Згідно 3 українською класифікацією товарів зовнішньоекономічної діяльності (УКТ ЗЕД) до систем оздоблення внутрішніх стін, у першу чергу, відносяться шпалери, які можуть вироблятися на різній основі та мають 3 лицьової сторони різні види покриття.

Сучасний асортимент шпалер представлено паперовими, вініловими, текстильними, джутовими, корковими, металевими, рідкими шпалерами, а також лінкрустом, шпалерами на основі серпянки, склошпалерами, шпалерами на основі деревного шпону, фотошпалерами, тафтинг-шпалерами 
тощо. Оскільки шпалери можуть суттєво відрізнятися матеріалом виготовлення і тим, у якому вигляді вони використовуються, створюються труднощі під час класифікаційної експертизи і визначення їх коду за УКТ ЗЕД.

Аналіз останніх досліджень, у яких започатковано вирішення проблеми. Однозначної класифікації шпалер згідно із різними класифікаторами, так само як i інших товарів, не існує. Стандартна класифікація шпалер наведена у ДСТУ ГОСТ 6810:2004 (ЕН 233-89) Шпалери. Технічні умови (ГОСТ 6810-2002 (ЕН 233-89), IDT) [5], відповідно до якого шпалери виготовляють наступних класів:

- паперові;

- вінілові;

- текстильні на паперовій основі;

- шпалери на основі із нетканих композиційних матеріалів (флізелінові).

Паперові та вінілові виготовляють 2 типів:

- гладкі;

- рельєфні.

За способом обробки верхньої сторони паперові та вінілові шпалери поділяють на види:

- тиснені, у тому числі тиснені фарбовані, тиснені з рапопортом, тиснені дуплекс; тиснені;

- профільні, у тому числі профільні спінені, профільні хімічно

- велюрові;

- $\quad$ металізовані, у тому числі ламіновані металевим шаром на основі фольги чи металізованої плівки, з металевим ефектом;

- необроблене паперове полотно;

- $\quad$ декоровані природною речовиною.

У декоративному виконанні шпалери виготовляють:

- фоновими;

- 3 друкованим малюнком і фоном;

- 3 друкованим (тисненим) малюнком без фону.

Залежно від стійкості верхньої сторони до тертя під час наклеювання та експлуатації шпалери вготовляють наступних марок:

- В-0 - водостійкі під час наклеювання;

- В-1 - водостійкі під час експлуатації; 
- $\quad$ М-1 - стійкі до миття;

- $\quad$ М-2 - з високою стійкістю до миття;

- $\quad$ М-3 - стійкі до тертя;

- $\quad$ С - стійкі до сухого тертя.

У торгівлі шпалери класифікують за наступними ознаками: призначенням, водостійкістю, виглядом поверхні, фактурою паперу, густиною, кількістю шарів, структурою декоративного покриття, залежно від малюнка. За статистичною класифікацією продукції (СКП) основні види шпалер відносяться до групи 17 «Папір та вироби 3 паперу» і мають код 17.24.11 «Шпалери та вироби 3 паперу для покриття стін подібні; папір прозорий для вікон» [6]. Державний класифікатор продукції та послуг (ДКПП) гармонізовано із СКП і відповідно шпалери за цим класифікатором мають код 17.24.11 «Шпалери і подібні настінні покриви; папір прозорий для вікон» [7].

За УКТ ЗЕД більшість шпалер відносяться до Х розділу «Маса 3 деревини або з інших волокнистих целюлозних матеріалів; папір або картон, одержані 3 відходів та макулатури; папір, картон та вироби 3 них». Примітки, що містяться у цьому розділі, розшифровують термін «шпалери та аналогічні настінні покриття» код 4814:

- папір у рулонах завширшки не менше ніж 45 см, але не більше 160 см, призначений для декорування стін або стелі;

- тиснений із пофарбованою поверхнею, друкованим малюнком або інакше декорований на поверхні (наприклад, з текстильним ворсом), покритий або не покритий захисним прозорим шаром пластмаси;

- із шорсткою поверхнею внаслідок додавання частинок дерева, соломи тощо;

- папір, покритий з лицьового боку пластмасою, при чому цей шар має зернисте або інше тиснення, фарбований, із друкованим малюнком або декорований інакше;

- покритий з лицьового боку матеріалом для плетіння, з'єднаним або не з'єднаним у паралельні смуги, або тканиною;

- бордюри та фризи з паперу, оброблені зазначеними вище способами, в рулонах або не в рулонах, придатні до декорування стін або стель;

- настінні покриття 3 паперу, виготовлені 3 декількох панелей, в рулонах або аркушах $з$ друкованим малюнком.

До перерахованих відносяться вінілові шпалери (як покриття - шар ПВХ), акрилові (як захисний водовідштовхувальний шар - акрилові емульсії), 
покриті поропластами, які після спучення утворюють рельєфні малюнки, текстильні, велюрові шпалери та фотошпалери [8].

На відсутність єдиного підходу до класифікації товарів під час проведення експертних товарознавчих досліджень і необхідність розробки єдиного методичного підходу до класифікації нехарчової продукції наголошують як науковці, так і практики [9-10]. Класифікація товарів повинна повністю охоплювати усі види продукції, що виготовляються; бути гнучкою, тобто забезпечувати включення, за необхідності, нових товарів, не порушуючи загальної схеми класифікації; враховувати майбутні зміни у номенклатурі й асортименті товарів; сприяти принципам кодування товарів і утворенню короткого шифру [10].

Цілі статті. Дослідження алгоритму кодування шпалер за УКТ ЗЕД 3 метою їх правильного митного оформлення. Завдання:

- вивчити особливості рідких шпалер як об’єкта класифікації для цілей митного оформлення;

- визначити код за УКТ ЗЕД рідких шпалер ТМ «Silk Plaster» (виробник - Латвія, імпортер в Україну - ТОВ «Фасад»), що реалізуються в «Епіцентр-К»;

- вияснити значення об'єму знань майбутніх товарознавців-експертів під час кодування рідких шпалер за УКТ ЗЕД.

Об’скт дослідження. Рідкі шпалери TM «Silk Plaster» (виробник Латвія, імпортер в Україну - ТОВ «Фасад»).

Методи дослідження. Системний аналіз, узагальнення i порівняння даних із проблеми дослідження на основі вивчення джерел літератури.

\section{Виклад основного матеріалу дослідження 3 повним обгрунтуванням} отриманих наукових результатів. В останні роки в сегменті оздоблюваних матеріалів для стін з'явився новий товар - рідкі шпалери. Вони відрізняються тим, що являють собою суху сипучу суміш, що складається зі спеціально підібраних компонентів: волокон бавовни, целюлози, вовни, шовку, акрилу, зв’язуючого компоненту - клею КМЦ. Рідкі шпалери надходять у зручній упаковці з поліетиленової плівки вже готовими до використання, необхідно лише додати воду в об'ємі, що передбачений рекомендаціями до використання. Цей вид шпалер має широку гаму кольорів і відтінків, до деяких 3 них додають спеціальні декоративні добавки, зокрема блискітки. Залежно від основних компонентів, що входять до складу рідких шпалер вирізняють такі їх види:

- целюлозні; 
- шовкові;

- шовково-целюлозні;

- бавовняні.

У мережевих гіпермаркетах 3 продажу будівельних товарів, до яких відноситься «Епіцентр-К» представлено широкий асортимент шпалер, у тому числі рідких. За останні роки динаміка продажів зростає, щорічний приріст складає 13-21 \% проти 7-9 \% у традиційних шпалер на паперовій основі.

У мережі «Епіцентр-К» представлено рідкі шпалери ТМ «Silk Plaster» (виробництво - Латвія), імпортером яких в Україну є ТОВ «Фасад» (м. Київ). Їх реалізація дозволена в Україні відповідно до висновку Державної санітарно-епідеміологічної експертизи №05.03.02-03/16820 від 18.05.2016 р.

Рідкі шпалери відрізняються від традиційних сировинним складом, технологією приготування i нанесенням, отже, їх класифікація і кодування теж будуть відрізнятися. За ДКПП рідкі шпалери мають код 20.30.12-90.00 «Фарби та лаки, інші, на основі синтетичних полімерів, н. в. і. У.», тобто вони віднесені до секції С «Продукція переробної промисловості» (20 «Речовини хімічні та хімічні продукти»; 20.30 «Фарби, лаки та подібні засоби для покриття, друкарські чорнила та суміші для ущільнення»; 20.30 .12 «Фарби та лаки на основі поліестерів, акрилових і вінілових полімерів у неводних середовищах; розчини»).

Побудова коду рідких шпалер за УКТ ЗЕД має теж свої особливості. Під час встановлення їх коду потрібно правильно і максимально точно відповісти на запитання: що це? із якого матеріалу виготовлено? для чого використовується? у якому вигляді використовується? А після визначення рівнів класифікації згідно з УКТ ЗЕД необхідно дати відповідь ще на одне запитання: чи єдине це угрупування, у якому досліджуваний товар описується?

Враховуючи зазначені рекомендації на першому етапі було встановлено рідкі шпалери є нехарчовою продукцією і відносяться до хімічної продукції, тобто можуть бути класифіковані у розділі IV «Продукція хімічної та пов'язаних 3 нею галузей промисловості». Цей розділ містить 11 груп. Аналіз приміток та пояснень до розділу IV та його груп дає можливість віднести рідкі шпалери до групи 32 «Екстракти дубильні або барвні; таніни та їх похідні, барвники, пігменти та інші фарбувальні матеріали, фарби і лаки, замазки та інші мастики; чорнило, туш».

За результатами аналізу назв товарних позицій у межах групи 32 рідкі шпалери класифікуються у товарній позиції 3214 «Замазки для скла, садові 
замазки, цементи смоляні, замазки (для ущільнення) та інші мастики; шпаклівки для малярних робіт; невогнетривкі суміші для підготовки поверхні фасадів, внутрішніх стін будівель; підлоги, стелі тощо». На основі пояснень до групи 32 рідкі шпалери можна віднести до невогнетривких сумішей для підготовлення поверхонь (з пояснень - невогнетривкі суміші використовуються для підготовлення поверхонь фасадів будівель, внутрішніх стін, підлоги і стель, бортиків і підлоги басейнів тощо, для надання їм водонепроникності та поліпшення зовнішнього вигляду. Зазвичай вони використовуються під час остаточного оброблення приміщень).

Таким чином, код рідких шпалер за УКТ ЗЕД -3214900090. Можливий опис для графи 31 митної декларації «Декоративне фінішне покриття для внутрішнього оздоблення стін та стелі (рідкі шпалери) TM «Silk Plaster», що являє собою багатокомпонентну суміш природних (целюлоза) та (або) синтетичних волокон, кольорових та декоративних домішок, загущувачів та присадок».

Висновки та перспективи подальших досліджень. Рідкі шпалери - це суха сипуча суміш, що складається зі спеціально підібраних компонентів: волокон бавовни, целюлози, вовни, шовку, акрилу, зв'язуючого компоненту клею карбоксиметилцелюлози (КМЦ). Вони стають готовими до використання після додавання необхідної відповідно до інструкції кількості води. Відрізняються ці шпалери широкою гамою кольорів і відтінків, до деяких $з$ них додають спеціальні декоративні добавки.

1.3 урахуванням складу, особливостей підготовки до використання i нанесення рідкі шпалери можуть бути класифіковані у розділі IV «Продукція хімічної та пов’язаних з нею галузей промисловості» та групі 32 «кстракти дубильні або барвні; таніни та їх похідні, барвники, пігменти та інші фарбувальні матеріали, фарби і лаки, замазки та інші мастики; чорнило, туш». На основі пояснень до групи 32 рідкі шпалери можна віднести до невогнетривких сумішей для підготовлення поверхонь. Отже, код рідких шпалер ТМ «Silk Plaster» за УКТ ЗЕД -3214900090.

2. Сьогодні товарознавці-експерти в митній справі повинні знати, що навіть товари 3 різних розділів УКТ ЗЕД можуть мати одне цільове призначення. Зокрема, для внутрішнього оздоблення приміщення можна використовувати не лише традиційні види шпалер, але, наприклад, і рідкі, що за своїм складом, способом підготовки до нанесення i власне нанесенням суттєво відрізняються від традиційних. Необхідно чітко усвідомлювати вимоги до них суттєво відрізняються. Це стосується як технічних вимог: 
міцності зчеплення 3 основою, адгезійної міцності, стійкості до тертя, світлостійкості, можливості пофарбування, так і одометричних властивостей. I це обов’язково потрібно враховувати під час проведення товарознавчих експертиз та наукових досліджень.

Таким чином, на нашу думку, існує потреба у внесенні необхідних змін в асортиментну класифікацію шпалер, тобто додаванні до неї опису рідких шпалер; у розробці системи експлуатаційних показників для шпалер різних типів 3 метою найбільшого задоволення потреб споживачів і у вивченні довговічності різних видів шпалер 3 метою встановлення міжремонтних циклів поточних ремонтів 3 повною або частковою заміною настінного покриття.

\section{Список використаних джерел}

1. Експорт та імпорт 2018 - чим заробляємо, на що витрачаємо? [Електронний pecypc] // Новини української економіки / Financer.com. - Режим доступу: https://financer.com/ua/eksport-import-2018. - Назва з екрана.

2. Про приєднання до Міжнародної конвенції про Гармонізовану систему опису та кодування товарів: Указ Президента № 466/2002 від 17.05.2002 р. [Електронний ресурс] // Законодавство України / Верховної Ради України. - Режим доступу: http://zakon4.rada.gov.ua/laws/show/466/2002. - Назва з екрана.

3. Міжнародна конвенції про Гармонізовану систему опису та кодування товарів: Конвенція Ради Міжнародного співробітництва від 14.06.1983 р. [Електронний ресурс] // Законодавство України / Верховної Ради України. - Режим доступу: http://zakon5.rada.gov.ua/laws/show/995_079. - Назва з екрана.

4. Войтов С. Г. Класифікація товарів як інструмент митно-тарифного регулювання: аспект визначення і контролю / С. Г. Войтов // Актуальні проблеми економіки. - 2013. - № 9. - C. $42-48$.

5. Шпалери. Технічні умови ДСТУ ГОСТ 6810:2004 (ЕН 233-89) [Електронний pecypc]. - Режим доступу: http:// standartgost.ru/g/ГОСТ\%208047-2001. - Назва з екрана.

6. Статистична класифікація продукції. [Електронний ресурс] // Державна служба статистики України.

Режим доступу: http://www.ukrstat.gov.ua/klasf/st_kls/op_skp_2016.htm. - Назва з екрана.

7. Державний класифікатор продукції та послуг: ДК 016:2010: наказ Держспоживстандарту України від 11. 10. 2010 № 457 [Електронний ресурс] // Законодавство України / Верховна Рада України. - Режим доступу: http://zakon3.rada.gov.ua/laws/show/326-93-\%D0\%BF. - Назва з екрана.

8. Про Митний тариф України: Закон України від 19.09. 2013 р. № 584-VII [Електронний ресурс] // Законодавство України / Верховна Рада України. - Режим доступу: https://zakon.rada.gov.ua/laws/show/584-18. - Назва з екрана.

9. Осієвська В. В. Проблеми класифікації деревного вугілля / В. В. Осієвська // Актуальні проблеми теорії і практики експертизи товарів: матеріали IV Міжнародної науково-практичної інтернет-конференції (м. Полтава, 20-22 березня 2017 року). Полтава: ПУЕТ, 2017: - С. 45-49. 
10. Мартосенко М. Г. Проблеми сучасної класифікації товарів під час проведення експертного товарознавчого дослідження / М. Г. Мартосенко, Н.Ф. Кострикіна // Підприємництво, торгівля: теоретичні підходи та практичні аспекти: матеріали I Міжнародної науково-практичної інтернет-конференції (м. Старобільськ, 27-28 листопада 2018 року). - Полтава: ПУЕТ, 2018: - С. 295-299.

Цель. Изучение алгоритма кодирования обоев по УКТВЭД с ичелью их таможенного оформления

Методика. При исследовании использованы системный анализ, методы обобщения и сравнения данных по проблеме исследования на основе изучения источников литературы

Результаты. Жидкие обои представляют собой сухую сыпучую смесь, состояшую из специиально подобранных компонентов: волокон хлопка, целлюлозы, шерсти, шелка, акрила и т.д., а также связующего компонента, то есть клея карбоксиметилцеллюлозы. Они также отличаются от традиционных обоев технологией приготовления и нанесения; их классификация и кодирование тоже имеет свои особенности. В сетевых магазинах «Эпицентр-К» представлены жидкие обои TM «Silk Plaster» (производство - Латвия), импортером которых в Украину является ООО «Фасад». Правильность их кодирования обеспечит бесперебойное выполнение работ при декларировании, четкость проведения таможенного контроля. По ДКПП жидкие обои имеют код 20.30.12-90.00 «Краски и лаки, другие, на основе синтетических полимеров», то есть они отнесены к секции С «Продукция перерабатывающей промышленности». При установлении кода по УКТВЭД сначала было установлено - жидкие обои являются непищевой продукцией и относятся к химической продукиии, то есть могут быть классифицированы в разделе IV «Продукиия химической и связанных с ней отраслей промыпленности». Этот раздел содержит 11 групп. Анализ примечаний и пояснений к разделу IV дает возможность отнести жидкие обои к группе 32 «Экстракты дубильные или красящие; танины и их производные, красители, пигменты и прочие красящие вещества, краски и лаки, шпатлевки и прочие мастики; чернила, тушь ». В соответствии с объяснениями к группе 32, жидкие обои это неогнеупорные смеси для подготовки поверхностей. Таким образом, код жидких обоев по УКТВЭД - 3214900090.

Научная новизна. Проведено изучение жидких обоев TM «Silk Plaster» как объекта классификации для иелей таможенного оформления, обоснование уровней классификации, предоставлено классификационное решение.

Практическое значение. Правильное определение кода жидких обоев TM «Silk Plaster» по УКТВЭД важно для тарифного и нетарифного регулирования, при обработке и подготовке международных документов, статистических наблюдениях и т.д.

Ключевые слова: кодирование, жидкие обои, классификаџия, ООО «Фасад», таможенное оформление, код УКТВЭД.

Purpose. Algorithm analysis of liquid wallpaper coding according to UKTZED with the purpose of the customs clearance.

Methodology. System analysis, generalization and data comparison methods based on literature searches have been used during the study.

Findings. Liquid wallpaper is a dry mixture consisting of specially selected components: cotton fibers, cellulose, wool, silk, acrylic, etc., and the binding component, that is, the carboxymethylcelluloseadhesive. They differ from traditional wall-paper in manufacturing and application technology; their classification and coding also have special features. Liquid wallpaper of «Silk Plaster» (production - Latvia), imported to Ukraine by - «Facad» LLC are on display in «Epicenter-K» chain stores. The correctness of coding will ensure the uninterrupted 
work completion during declaration, and the accuracy of customs control. According to DKPP liquid wallpaper have code 20.30.12-90.00 «Paints and varnishes, others, based on synthetic polymers», that is, they are referred to Section $C$ "Production of the processing industry». When constructing the code of liquid wallpaper for UKTZED, it was primarily found that liquid wallpaper belongs to non-food products and refers to chemical production, $i$. e. it can be classified in Section IV "Production of Chemicals \& Allied Industries». This section contains 11 groups. Analysis of the explanatory notes to Section IV makes it possible to refer the liquid wallpaper to group 32 TANNING OR DYEING EXTRACTS; TANNINS AND THEIR DERIVATIVES; DYES, PIGMENTS AND OTHER COLOURING MATTER; PAINTS, VARNISHES; PUTTY, OTHER MASTICS; INKS. According to the explanatory note for group 32 liquid wallpaper is of non-fire resistant mixture for the surface preparation. Therefore, the code of liquid wallpaper according to UKTZED is 3214900090.

Originality. The study of liquid wallpaper "Silk Plaster» as the object of classification for the purpose of customs clearance is carried out, the justification of the levels of classification, the classification decision are given.

The practical value. The correct definition of the code of liquid wallpaper of «Silk Plaster» for UKTZED is important for tariff and non-tariff regulation, during processing and preparation of international documents, statistical observations, etc.

Keywords: coding, liquid wallpaper, classification, «Fasad» LLC, customs clearance, code, UKTZED

Рекомендовано до публікації доктором технічних наук, професором КНУБА Ляліною Н.П. Дата надходження в редакиію 09.02.2019 p. 